\title{
EFFECT OF LOCAL UV RADIATION ON THE MORPHOFUNCTIONAL STATE OF THE SKIN OF GUINEA PIGS IN EARLY AND REMOTE PERIODS AFTER IRRADIATION
}

DOI: 10.36740/WLek202004115

\author{
Tetyana V. Zvyagintseva' ${ }^{1}$ Svitlana I. Myronchenko ${ }^{2}$, Nataliia I. Kytsiuk ${ }^{3}$, Olga V. Naumova ${ }^{4}$ \\ 'STATE INSTITUTION «ROMODANOV NEUROSURGERY INSTITUTE OF NATIONAL ACADEMY OF MEDICAL SCIENCES OF UKRAINE», KYIV, UKRAINE \\ 2NATIONAL UNIVERSITY OF PHARMACY, KHARKIV, UKRAINE \\ 3STATE INSTITUTION “UKRAINIAN RESEARCH INSTITUTE OF TRANSPORT MEDICINE OF THE MINISTRY OF HEALTH OF UKRAINE”, ODESA, UKRAINE \\ ${ }^{4}$ KHARKIV NATIONAL MEDICAL UNIVERSITY, KHARKIV, UKRAINE
}

\begin{abstract}
The aim is to establish the features of morphological and morphometric changes in the skin of guinea pigs in erythemal, early post-erythemal and late post-erythemic periods after local ultraviolet irradiation.

Materials and methods: Studies were conducted on 54 albino guinea pigs weighing 400-500 g. Ultraviolet erythema was caused by irradiation in 1 minimum erythemal dose. The control group included intact guinea pigs. After 2, 4 hours, on the 3rd, 8th, 15th, 21st, 28th day, the fragments of the irradiated skin were investigated using histochemical and morphometric methods.

Results: After 2, 4 hours after irradiation, dyscirculatory changes in the skin develop. By the 3rd day of the experiment a morphological picture of acute inflammation in the epidermis and dermis develops, apoptotic keratinocytes appear (sunburn cells), which is accompanied by thickening of the epidermis and an increase in the density of fibroblasts. By the 8th day proliferative-hyperplastic and degenerative changes begin to prevail, including dystrophic nature, the thickness of the epidermis and the density of fibroblasts reach a maximum. In the long term, on the 15-28th day, dystrophic changes of the epidermis, dyskeratosis, changes in the number and structure of elastic fibers with an increase in uneven fibrosis, collagenization processes and the development of sclerotic changes, as well as a significant thickening of the epidermis, an increase in the density of fibroblasts are observed.
\end{abstract}

Conclusions: The data obtained indicate pronounced morphofunctional changes in the skin in the zone of local ultraviolet irradiation observed throughout the entire observation period.

KEY WORDS: ultraviolet irradiation, skin, morphological and morphometric methods, density of fibroblasts, thickness of epidermis

Wiad Lek. 2020;73(4):705-707

\section{INTRODUCTION}

The study which involved a model of ultraviolet (UV) erythema in guinea pigs showed morphological picture of acute inflammation in the skin of animals during the first 3 days after irradiation [1,2]. Moreover, in the time range of 2-4 hours - the 3rd day, histopathological changes reach a maximum by the 3rd day, although the severity of the erythema begins to decrease (the maximum of the erythema reaction was recorded 4 hours after irradiation). The disappearance of erythema (8th day after ultraviolet irradiation (UVI)) was not accompanied by a cessation of the development of histopathological processes in the skin, but their quality changed. Exudation was followed by the development of hyperplastic processes in the epidermis, collagenization of the dermis, which indicates that the process is chronized [1]. The discrepancy in the time course of the erythemic reaction and the severity of inflammatory changes in the skin after UVI, as well as the clinical "lag" period, during which inflammatory and degenerative changes of a dystrophic nature develop, became the reason for a closer study of the morphological processes occurring in the early and the post-irradiation period. We placed special emphasis on morphometric studies, which make it possible to objectively assess the state of histological structures, to identify patterns of pathological, compensatory and regenerative processes in them $[3,4,5]$.

\section{THE AIM}

The aim was to establish the features of morphological and morphometric changes in the skin of guinea pigs in the erythemic, early post-erythemic and late post-erythemic periods after the local ultraviolet irradiation.

\section{MATERIALS AND METHODS}

The studies involved 54 albino guinea pigs weighing 400-500 g. Erythema was caused by irradiation in 1 minimum erythemic dose (1 MED) of the shaved skin area using a mercury-quartz illuminator OKN-11-M (UV rays A and B), placed at a distance of $10 \mathrm{~cm}$ from the animal, for 2 minutes. In this case, the 
Table I. The thickness of the epidermis (TE) and the density of fibroblasts (DF) in the focus of the local UVI in different periods of observation

\begin{tabular}{|c|c|c|c|c|c|c|c|c|}
\hline \multirow{2}{*}{ Indices } & \multirow{2}{*}{$\begin{array}{l}\text { Intact } \\
\text { animals }\end{array}$} & \multicolumn{7}{|c|}{ Animals exposed to local UVI } \\
\hline & & 2 hours & 4 hours & 3rd day & 8th day & 15th day & 21st day & 28th day \\
\hline $\begin{array}{c}\mathrm{TE}, \\
\mathrm{mcm}\end{array}$ & $\begin{array}{c}34.12 \pm \\
1.73\end{array}$ & $\begin{array}{c}32.05 \pm \\
1.82\end{array}$ & $\begin{array}{c}40.76 \pm \\
2.07^{*}\end{array}$ & $\begin{array}{c}63.04 \pm \\
4.53^{*}\end{array}$ & $\begin{array}{c}114.64 \pm \\
3.23^{*}\end{array}$ & $\begin{array}{c}90.59 \pm \\
3.17^{*}\end{array}$ & $\begin{array}{c}78.27 \pm \\
29^{*}\end{array}$ & $\begin{array}{c}69.16 \pm \\
3.00^{*}\end{array}$ \\
\hline $\begin{array}{l}\text { DF in derma, } \\
\mathrm{sp} / \mathrm{mm}^{2}\end{array}$ & $\begin{array}{c}493.90 \pm \\
12.60\end{array}$ & $\begin{array}{c}480.68 \pm \\
24.21\end{array}$ & $\begin{array}{c}419.8 \pm \\
41.45\end{array}$ & $\begin{array}{c}960.57 \pm \\
41.45^{*}\end{array}$ & $\begin{array}{c}1861.11 \pm \\
74.32^{*}\end{array}$ & $\begin{array}{c}1760.41 \pm \\
86.19^{*}\end{array}$ & $\begin{array}{c}1267.67 \pm \\
62.26^{*}\end{array}$ & $\begin{array}{c}1041.02 \pm \\
39.51^{*}\end{array}$ \\
\hline
\end{tabular}

Note. ${ }^{*}$ - significant differences in comparison with the intact animals ( $\mathrm{p} \leq 0.05$ )

skin area was shielded with a circular plate having five holes with a diameter of $6 \mathrm{~mm}$. The degree of reaction was evaluated after 2, 4 hours, 3 days after irradiation and until the erythema disappeared in points for each spot: 0 - no erythema, 1 - clear redness, 2 - intense erythema. The intensity of 5 spots was summed up. The level of the damaging effect was assessed by the intensity and duration of the erythemic reaction, swelling, compaction, and pain of the irradiated zone [6]. The overall reactions (behavior, appetite, body weight, condition of hair, body temperature) were assessed. The control group included intact guinea pigs. To study the peculiarities of the morphological changes of the skin after local UVI, animals of all groups were removed from the experiment under general anesthesia (sodium thiopental at a dose of $60 \mathrm{mg} \mathrm{kg}$ ) at different periods of the experiment ( 2 hours, 4 hours, 3 days, 8 days, 15 th day, 21 st day, 28 th day) in compliance with the requirements of the European Convention for the Protection of Vertebrate Animals, used for research and other scientific purposes (Strasburg, 1986). Skin fragments were fixed in $10 \%$ neutral formalin, after which sections about $4 \mathrm{~mm}$ thick were dissected out. The material was subjected to alcohol wiring and paraffin casting, sections were made with a thickness of 5-6 microns. Survey drugs stained with hematoxylin and eosin were used for a general assessment of the state of the tissues examined. Weigert's staining of fuchselin preparations for elastic fibers with van Gieson picro-fuchsin staining was used to identify and differentiate connective tissue structures $[7,8]$. For the objectification of the obtained data, morphometric methods were used to study sunburn cells, leukocyte infiltration of the dermis and epidermis, changes in collagen and elastic fibers, dermo-epidermal activity, thickness of the epidermis and density of fibroblasts in the dermis $[3,9,10]$.

The study of microscopic specimens, as well as morphometric studies, was carried out on an Olympus BX-41 microscope using Olympus DP-Soft (Version 3: 1) and Microsoft Excel [2] software.

\section{RESULTS AND DISCUSSION}

The results of our numerous experiments allowed us to conditionally distinguish 3 periods in the action of the UVI: early erythemic up to 3 days, early post-erythemic up to 8 days and late post-erythemic (15-28 days) $[1,2,11]$.

Our observations of local manifestations of irradiated skin after the disappearance of erythema (days 8-28) did not reveal any pathological changes (puffiness, compaction, pain of the irradiated zone). There were also no violations in the overall reaction of the organism.
The early erythema period was characterized by inflammatory-degenerative changes in the skin, reaching the highest severity on the 3 rd day after irradiation. In the early periods after the UVI (2 and 4 hours), dyscirculatory changes were observed, combined with vacuolization in the area of the dermo-epidermal junction. As follows from the table, during morphometric study, the thickness of the epidermis and the density of fibroblasts after 2 hours in irradiated animals did not significantly differ from those in intact guinea pigs (table I).

After 4 hours of UVI, histological changes increased, accompanied by leukocyte infiltration of the dermis, minor changes in the collagen and elastic fibers of the dermis. There were apoptotically modified keratinocytes (sunburn cells), a significant increase in which was confirmed by morphometric studies. Four hours after the UVI, an increase in the thickness of the epidermis was revealed by a factor of 1.2 compared with intact animals. The density of fibroblasts had a tendency to decrease, which was associated with edema of the dermis, however, it did not significantly differ from that in intact animals (table I). On the 3rd day of the experiment, numerous sunburn cells were present in the skin, there were signs of dermo-epidermal activity, marked leukocyte infiltration of the dermis, destruction of collagen and elastic fibers, as evidenced by morphometry of histological preparations $[1,2,11]$. By the 3 rd day of the experiment, the thickness of the epidermis was significantly higher by 1.8 times than that of intact animals. In areas of the dermis adjacent to the loci of degenerative and destructive changes in the dermo-epidermal junction, a mild focal proliferation of fibroblasts was determined, the density of which increased 1.9 times as compared to the group of intact animals (table I).

In the early post-erythemic period (8th day) proliferative-hyperplastic and degenerative changes, including dystrophic ones, grew morphologically in the skin (morphometrically confirmed (violations of the structure of collagen and elastic fibers). On the 8th day after the UVI, as follows from the table, the thickness of the epidermis reached a maximum: it exceeded the norm by 3.4 times, mainly due to the spinous, granular and horny layer. The density of fibroblasts on the 8th day was also maximum (see table I), it exceeded the norm by 3.8 times (table I).

Over time (8-15 days), epidermal and dermal leukocytes were found in the form of small focal infiltrates consisting of polymorphonuclear leukocytes. Severe leukocyte infiltration progressively reduced. In the long term, on the 15-28th day, multiple thickening of the epidermis, an increase in the 
density of fibroblasts, dystrophic changes of epidermocytes, dyskeratosis, changes in the number and structure of elastic fibers with an increase in uneven fibrosis, collagenization processes and the development of sclerotic changes were observed [4]. On the 15th day, the thickness of the epidermis was above the norm by 2.7 times, slightly decreasing in comparison on the 8th day. A similar trend was observed with respect to fibroblasts. The density of fibroblasts was 3.5 times higher than normal. On the 21st day, the thickness of the epidermis exceeded the norm by 2.3 times, the density of fibroblasts - by 2.6 times. On the 28th day, the thickness of the epidermis and the density of fibroblasts were still higher than normal ( 2 times and 2.1 times, respectively) (table I).

Thus, even in the later periods after the UVI, in the absence of local manifestations in the skin of guinea pigs and the general response of the animal, at $100 \%$ of morphological changes in the number and structure of elastic fibers, the development of uneven fibrosis, collagenization with subsequent sclerotic changes were detected Consequently, a local single UVI of the skin of guinea pigs in 1 MED leads to prolonged histopathological disorders in the source of radiation.

\section{CONCLUSIONS}

1. The early erythema period is characterized by inflammatory and degenerative changes in the skin, which is manifested by a gradual thickening of the epidermis, vacuole degeneration and the appearance of apoptosis-altered epidermocytes (sunburn cells), impairment of the dermo-epidermal junction, leukocytic infiltration of the dermis, focal proliferation of the fibroblasts with an increase in their density; destructive changes of collagen and elastic fibers of the dermis.

2. Early post-erythemic period (8th day) is characterized by a maximum thickening of the epidermis, an increase in the density of fibroblasts, the appearance (increase) of dystrophic changes of the epidermis, and dyskeratosis, a thickening of collagen and elastic fibers.

3. In the late post-erythemic period (15th-28th day), the thickness of the epidermis and the density of fibroblasts gradually decrease, but in all periods the indices significantly exceed the norm. The number of elastic fibers decreases, their structure is impaired with a predominance of uneven fibrosis, collagenization and sclerotic disorders.

The detected morphofunctional disorders of the skin in the local UVI zone actualizes the problem of developing therapeutic and preventive measures based on the establishment of the mechanisms of the damaging effect of ultraviolet radiation, which will be the task of our future research.

\section{REFERENCES}

1. Myronchenko S.I., Zvyagintseva T.V., Naumova O.V. The impact of ultraviolet irradiation on morpho-functional state of the skin in guinea pigs. Georgian Medical News. 2016; 11 (260): 95-100.

2. Mironchenko S.I., Naumova O.V., Zvyagintseva T.V. Morphological changes in the skin of guinea pigs in local exposure to ultraviolet irradiation. European Journal of Natural History. 2016; 6: 28-31.
3. Avtandilov G. G. Osnovy kolichestvennoy patologicheskoy anatomii [Basics of quantitative pathological anatomy]. Moskva: Meditsina; 2002, 240 p. (In Russian)

4. Zvyagintseva T.V., Grin V. V., Naumova 0. V. Vliyanie fotoprotektorov na morfologicheskoe sostoyanie kozhi pri eksperimentalnom lokalnom ultrafioletovom obluchenii [The influence of photoprotectors on morphological state of skin in experimental local ultraviolet irradiation]. Meditsina segodnya i zavtra. 2013;1 (58): 59-63. (In Russian)

5. Kramar S.B. Morfologichni ta morfometrychni zminy kraiovoi ta tsentralnoi dilyanok opikovoi rany pislya eksperymentalnoi termichnoi travmy [Morphological and morphometric changes marginal and central areas of peak wounds after experimental thermal injury]. Svit biologii ta medytsyny. 2015; 3: 92-96. (In Ukranian)

6. Stefanov A. V. Bioskrining. Lekarstvennye sredstva. [Bioscreening. Drugs]. Kiev: Avitsenna; 1998, 189 p. (In Russian)

7. Lilli R. Patogistologicheskaya tekhnika i prakticheskaya gistohimiya [Pathohistological technique and practical histochemistry]. Moskva: World; 1960, 648 p. (In Russian)

8. Pirs E.Gistohimiya (teoreticheskayai prikladnaya) [Histochemistry (theoretical and applied)]. Moskva: Inostrannaya literatura; 1962, 962 p. (In Russian)

9. Sevin A., Oztaş P., Senen D. et al. Effects of polyphenols on skin damage due to ultraviolet A rays: an experimental study on rats. J Eur Acad Dermatol Venereol. 2007; 21 (5): 650-656.

10. Atramentova L.A., Utevskaya 0.M. Statisticheskie metody v biologii [Statistical methods in biology]. Gorlovka, 2008. 247 p. (In Russian)

11. Kitsyuk N.I. Morfologichni zminy shkiry morskikh svinok pry dii lokalnogo ultrafioletovogo oprominennya u viddaleni terminy [Morphological changes ofthe guinea pigsskin after action of local UV-radiation in longterm deadlines]. Aktualni problemy transportnoi medytsyny: navkolyshnie seredovyshchie; profesiine zdorovia; patologiia. - 2018;2 (52): 131-135. (In Ukranian)

\section{ORCID and contributionship:}

Tetyana V. Zvyagintseva - 0000-0001-9114-7742 ${ }^{A, E, F}$

Svitlana I. Myronchenko - 0000-0002-5367-2834 ${ }^{B, D}$

Nataliia I. Kytsiuk - 0000-0002-5367-2834 ${ }^{B, D}$

Olga V. Naumova - 0000-0003-3222-5426 ${ }^{B, C}$

\section{Conflicts of interest:}

Authors declare no conflict of interest.

\section{CORRESPONDING AUTHOR Tetyana V.Zvyagintseva}

State Institution «Romodanov Neurosurgery Institute

of National Academy of Medical Sciences of Ukraine»

Department of Experimental Neurosurgery and Clinical Pharmacology

22, apt. 27 Novhorodska str., 61145, Kharkiv, Ukraine

tel: +380672614663

e-mail: tana_zv@ukr.net

Received: 25.06 .2019

Accepted: 03.02.2020

A - Work concept and design, B - Data collection and analysis, C - Responsibility for statistical analysis,

D-Writing the article, $\mathbf{E}$-Critical review, $\mathbf{F}$-Final approval of the article 